\title{
Plagues, past, and futures for the Yagan canoe people of Cape Horn, southern Chile
}

\author{
Gustavo Blanco-Wells ${ }^{1,2,3}$ (1) $\cdot$ Macarena Libuy $^{2}$ (D) $\cdot$ Alberto Harambour ${ }^{1,2}$ (D) $\cdot$ Karina Rodríguez $^{4}$
}

Received: 1 September 2020 / Accepted: 9 February 2021 / Published online: 25 February 2021

(C) The Author(s), under exclusive licence to Springer-Verlag GmbH, DE part of Springer Nature 2021

\begin{abstract}
The manner in which the COVID-19 pandemic has affected the indigenous Yagan people of Navarino Island in southern Chile is the topic of this paper. Like other First Nation communities, these nomadic people suffered decimation and disease in successive encounters with Europeans, and then, in the mid-twentieth century, forced sedentarization by the Chilean State. More recently, the Yagan have fought the expansion of salmon aquaculture to the Island. Making use of a sociomaterial approach, we examine how the threat of past and present viruses and diseases, added to the tragic effects of colonization, become part of a broader sociohistorical debate on the right of coastal peoples to their maritories. Paradoxically, our results suggest that COVID-19 has become part of an assemblage of ethnic revitalization, opening possibilities for the Yagan clans to make some of their envisioned futures possible.
\end{abstract}

Keywords COVID-19 Canoe people $\cdot$ Futurities $\cdot$ Ethnic revitalization $\cdot$ Colonization $\cdot$ Cape Horn archipelago $\cdot$ Chile

\section{Introduction}

This article reflects the results of an unanticipated research effort among the Yagan people of Navarino Island in southern Chile. As one of the authors was due to set off for fieldwork in March 2020, news of the COVID-19 virus' advance ${ }^{1}$ through Latin America and its first confirmed contagion in Chile on March 3rd put us on the alert. The trip involved traveling by

\footnotetext{
${ }^{1}$ Eben Kirksey $(2020,11)$ points out that according to the Coronavirus Study Group, "the pandemic strain is recognized as a member of an existing viral species: severe acute respiratory syndrome-related coronavirus, or SARS$\mathrm{CoV}$. Officially, these taxonomists suggest that the proper name should be SARS-CoV-2." COVID-19 is the name given by the World Health Organization to the Coronavirus disease of 2019. In this paper, we will use COVID-19 in reference to the disease and SARS-CoV-2 when specifically referring to the virus.
}

Gustavo Blanco-Wells

gblanco@uach.cl

1 Instituto de Historia y Ciencias Sociales, Universidad Austral de Chile, Valdivia, Chile

2 Centro de Investigación en Dinámicas de Ecosistemas Marinos de Altas Latitudes, Valdivia, Chile

3 Centro de Ciencias del Clima y la Resiliencia, Santiago, Chile

4 Museo Antropológico Martín Gusinde, Puerto Williams, Chile buses and planes to cover the almost 2,800 km between the city of Valdivia, our research center's headquarters, and Navarino Island in the Cape Horn municipality. The journey implied the possibility of becoming exposed to the virus, putting the inhabitants of Puerto Williams - the native Yagan people among them - at risk. As a first nation, they did suffer devastating effects of other contagions since the beginning of European colonization in the mid-nineteenth century. The following is an account of how the virus changed the nature of fieldwork, as well as the sociopolitical trajectories of the Yagan.

\section{Uncertainties}

The fast spread of the new virus ${ }^{2}$ led us to rethink our fieldwork. Exchanging calls with our local counterparts and inquiring about airline ticket changes, daily reviews of the virus'

\footnotetext{
${ }^{2}$ At the end of December 2020, and according to official data, Chile presents 698,047 confirmed infections and 22,264 related deaths from the virus. The Magellan Region presents 18,529 confirmed infections and 302 related deaths. The commune of Cape Horn has registered 252 infected and 12 active cases and has no deceased (see https://www.minsal.cl/wp-content/uploads/2021/01/ Informe-Epidemiol\%C3\%B3gico-82.pdf). The veracity of early COVID-19 data and effectiveness of pandemic policies by the Chilean Government has been questioned by relevant independent actors leading to the resignation of the Minister of Health in mid-June 2020.
} 
progress in the news, and conversations between researchers on the urgency of the situation became part of our daily routine. Faced with the uncertainty that was unfolding, we decided not to travel until conditions were safe for everyone.

On March 21st, just a few days after the team decided to cancel fieldwork, the first contagion was registered in Puerto Williams and, on March 23rd, Navarino Island went into total lockdown. The virus had now reached the southernmost human community in the world. By March 21st, the Yagan Community of Bahía Mejillones ${ }^{3}$ issued a statement asking for an effective lockdown and new measures of protection. The text reads as follows:

"We are the southernmost native people in the world; we have inhabited this territory for more than 7,000 years. Many of our ancestors died of diseases brought from the outside by Europeans. Today, we acknowledge with fear and frustration how history might repeat itself ${ }^{4}$

The uncertainty triggered by the virus, added to this Yagan statement, sparked a reflection that we considered of interest. The relationship between COVID-19 and indigenous peoples is gaining rapid visibility in the international media and academic publications, as the historical evidence on the interdependence between colonization, viruses, bacteria, and their tragic impact on native peoples is revisited (Wade 2020). Several works address the crisis from the perspective of the responses of healthcare systems to the specific epidemiological characteristics of native populations (Cupertino et al. 2020; Gonçalves et al. 2020; McLeod et al. 2020; Meneses et al. 2020). Other works note the differentiated effects of COVID-19 on these populations, due also to their histories of marginalization (Power et al. 2020; White 2020). The effect of poor decision-making on vulnerable indigenous populations is also highlighted (Ferrante and Fearnside 2020).

In the case of Chile, the responses of indigenous peoples to the pandemic have varied. In the north, Atacameño communities decided to carry out their own self-quarantines; in central Chile, indigenous peoples' organizations combined self-managed actions in relation to their health systems and government programs; and, in the south, Mapuche communities exerted territorial control to handle the risks and care associated with the pandemic. All of them have demanded special policies for indigenous people during the pandemic, appealing to the International Labor Organization (ILO)

\footnotetext{
3 The Yagan Community of Bahía Mejillones was formed on November 21st of 1994, within the framework of the Indigenous Law $N^{\circ} 19253$ promulgated in 1993. The law also created the agency responsible for the implementation of indigenous policy: the National Indigenous Development Corporation (in Spanish CONADI). Financial support for indigenous initiatives was associated with, and often conditional on, the legal formation of communities and associations (Gundermann and Vergara 2009).

${ }^{4}$ Available at Radio Polar http://radiopolar.com/noticia_156221.html. Consulted on April 62020.
}

Convention 169, the Inter-American Commission on Human Rights, and other international institutions ${ }^{5}$.

These claims are in line with indigenous voices worldwide: "Going forward, data is needed to meticulously document the damage, naming us by our countries, our communities, our clans, and our tribes. So that the next time disease sweeps our planet, we know our weaknesses, we know our strengths, and if more informed and empowered, we will prevail against the next neo colonial wave" (Power et al. 2020, 2739).

Recognizing the importance of these reflections on the impact of COVID-19 on indigenous people, in this article, we explore the joint possibilities of remote ethnography and historiography to record the development of this pandemic in the world's southernmost coastal town, so as to understand, from a sociomaterial perspective, both the effects that it has on the Yagan people and the futures that it could make possible. A relational materiality approach, which in this case is constituted by inter-ethnic and inter-species relationships, allows us to understand the virus not only as an agent of disease and poverty creating relationships that kill or make life difficult but it also unveils plausible futures that occur in a process of ethnic revitalization and re-politicization.

What we call the sociomaterial approach is a theoretical grouping related to post-humanism, finding its common denominator in the ideas of Deleuze and Guattari (1988) and translating into an understanding of the agency of bodies and materials, organic and inorganic, and their mutual constitution in multiple and open forms of coexistence. This grouping includes a variety of theoretical branches: new materialisms, actor-network theory, affect theories, assemblage theory, non-representational theory, speculative realism, and vital materialism, and authors as diverse as Isabelle Stengers, Bruno Latour, Donna Haraway, Anna Tsing, Jane Bennet, Manuel De Landa, and Brian Massumi among the most prominent (Wolfe 2010; Grusin 2015; Chandler 2018). Posthumanism also finds epistemic affinity with some of the approaches of the so-called ontological turn, and, of particular interest for this work, with the political ontology of Latin American authors such as Arturo Escobar, Mario Blaser, Marisol de la Cadena, and Eduardo Kohn (Holbraad and Pedersen 2017). The ontological turn would have, as a shared element, a common diagnosis: we would be witnessing a broader type of change, "the specter of a global ecological crisis" (Kohn 2015) that urges us to explore possibilities of conviviality beyond the modern tools of science, democracy, and capitalism. Political ontology recognizes the pluriverse of entities that populate the world such as experienced by indigenous territoriality in which the human, non-human, and more-than-human are heterogeneously associated. In this

\footnotetext{
${ }^{5}$ Available at https://www.re-vuelta.cl/2020/07/10/organizaciones-depueblos-originarios-dan-a-conocer-12-propuestas-como-exigencia-frente-alestado-por-pandemia/. Consulted on July 152020.
} 
perspective, the peoples of Latin American territories live, name, and represent worlds (or parts of worlds) in an ontologically different manner than is done through Eurocentric and technocratic rationality (De la Cadena 2015; De la Cadena and Blaser 2018); so, most of the conflicts-environmental or otherwise - arise from the inability of modern rational epistemologies to understand certain relationships between humans and other natures (Blaser 2013; Escobar 2015). Pauwelussen (2020), in her comment on the Manifesto for the marine social sciences (Bavinck and Verrip 2020), identifies the existence of epistemological and ontological diversity as part of an invitation to decolonize marine sciences. Mather et al. (2017) have also noted the shift from exclusively epistemological questions raised by maritime scholarship towards an engagement with ontological ones, from a concern about how our theories and methods are not mere representations but are "world making."

In the line of sociomaterial approaches, we are interested in the recent contributions of authors who think of COVID-19 relationally and in counterpoint to explanatory reductionisms that reproduce the nature/culture dichotomy and maintain others such as East/West. For example, Kirksey (2020) proposes that COVID-19 is a multi-species assemblage whose relationality allows for the overcoming of ethnocentric determinism - in relation to its origin in China —or anthropocentricity-its relation to the role of certain exotic species. Coronaviruses are part of "a tangled web of relations, with jumping genes that defy human attempts to cordon off species from one another" (Kirksey 2020, 12), with humans being the main global carrier. Linde-Ozole $(2020,1)$ reminds us of the limits of the pretention of control in this human-virus relationality: "COVID-19 clearly has shown that these viral agents are unpredictable, unknowable, and difficult to manage, shattering the Pasteurian dream (n.b., a germ-free world without pathogenic presence) and showing that our lives cannot that easily be disentangled from non-human agents." Searle and Turnbull (2020) use a more-than-human perspective to criticize both the simplified view of nature's reemergence that the pandemic would be triggering and the purely biological understanding of virus transmission without considering the uneven distribution between different peoples, genders, classes, and geographies.

In methodological terms, the presence of this virus confronts us with questions for the development of our research and the position of the ethnographers. Pandemic restrictions also demanded a rethinking of methodology such as participant observation. In addition to historiographic archive review and the consulting of contemporary press and other documents, we applied strategies of what is known as remote ethnography (Postill 2017), carrying out seven in-depth telephone interviews in the period between May and August 2020. Altogether, this work was supported from Puerto Williams by one of the researchers who has lived in this town for 6 years, so that her experience allowed us to remotely ground the findings in the local contexts. Although remote or virtual ethnography is rather focused on the possibilities offered by digital media, we methodologically adapted it to forms of in-depth dialogues mediated by communication technologies, such as telephone and video calls. This was particularly relevant given the complex physical and digital connectivities of the archipelago. We insist on the ethnographic orientation of our work, although we are unable to fulfill the classic role of ethnography of "being there," we understand that its practice, in our case, is not restricted to remote interaction techniques but is based on a previous ethnographic relationship with local communities. From this perspective, the article is based on 5 years of regional fieldwork considered, for research purposes, as an extended case study (Burawoy, 1998).

Our narrative is organized under concepts that represent the various phases of the case as it unfolds. This introductory section carries the heading uncertainties. Contingencies documents the evolution of the pandemic in Puerto Williams and Villa Ukika and situates the maritory ${ }^{6}$ in relation to development processes relevant to its population, particularly for the Yagan people. Memories examine dramatic situations triggered by viruses and bacteria following encounters between the southernmost canoe peoples and colonial enterprise. Futurities sketches the prospects of these maritories on the basis of Yagan voices regarding the spreading out and copresence of the virus. Finally, in multiplicities, we offer a joint discussion and conclusion on the sociomaterial assemblages emerging from the SARS-Cov-2 crisis and the politics of life of the southernmost people of the world.

\section{Contingencies}

Puerto Williams is located on the northern coast of Navarino Island in the Beagle Channel, and it is part of the Cape Horn archipelago in the Magellan Region (see Fig. 1). Among its almost 2000 inhabitants are the descendants of the Yagan canoe people, most of whom belong to the "Comunidad Yagán Bahía Mejillones," composed of 94 people.

Faced with the threat of viral spread when the first case was registered on March 21st, the Yagan representatives made a call to authorities, demanding the closure of the island and a complete lockdown. On that same day, the Chilean government declared a curfew in the entire nation and a total quarantine for Puerto Williams. This was the beginning of a period

\footnotetext{
${ }^{6}$ Translated from Spanish maritorio, "is a notion centered on the lived space, the modes of dwelling, mobilizing, and producing of cultural groups that develop in intimate relationship with the sea and the coastal zone, forming an inseparable whole" (Blanco et al. 2019:46). Its use in Chile has spread to depict in particular the coastal and marine interface of the archipelagic areas of Chiloé to Magallanes (Álvarez et al. 2019).
} 


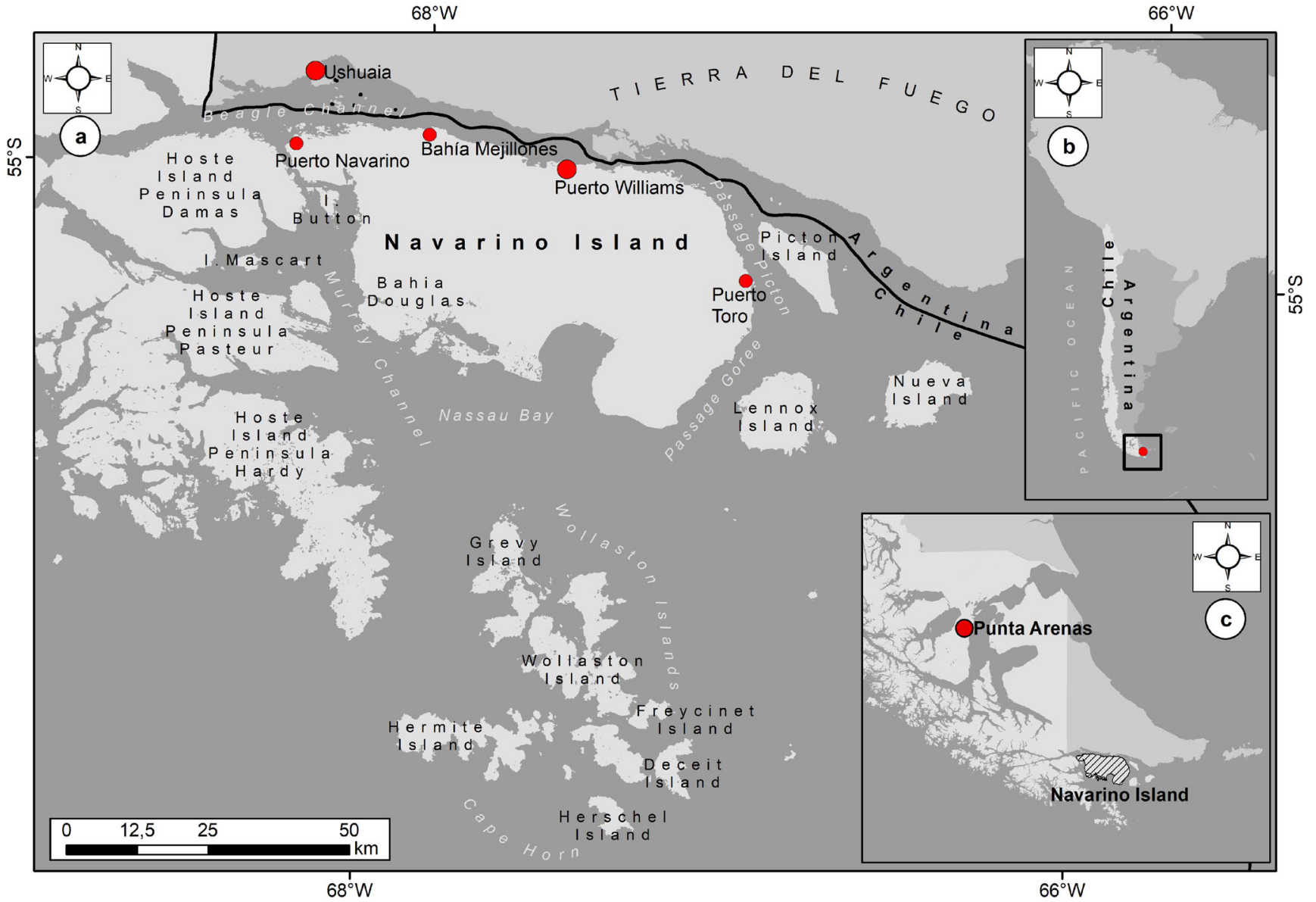

Fig. 1 Map of the Cape Horn Archipelago. Source: authors

of confinement, which implied that planes and boats could come and go from the island only to transport foodstuff, supplies for healthcare services, basic goods, or for medical emergencies, and that local people could only leave their homes in situations defined by authorities and controlled by the navy. Most activities ceased, public offices suspended in-person services and stores began to deliver to homes.

On April 6th, after nine cases of contagion, lockdown was replaced by a "cordon sanitaire" (health screening and proof of residence to enter or leave the island). Local authorities and the Yagan community deemed this measure, which is still in place at the time of writing, inadequate. During April 2020, Yagan representatives expressed their disapproval in the press, bringing forward brutal events from their past in their demand for total quarantine: "along with assimilation policies, it was the epidemics caused by bacteriologic contact generated by the arrival of sailors, missionaries, and foreign colonists that pushed our people to the brink of extinction." referring to events that occurred during the second half of the 19th century. Among their concerns, the care of their elders-

\footnotetext{
${ }^{7}$ Available at:https://observatorio.cl/comunicado-de-alerta-de-la-comunidadindigena-yagan-de-bahia-mejillones-frente-al-covid-19/. Consulted on July 152020 .
}

10 members of the community - was a crucial issue ${ }^{8}$. On a national level, no specific protocol for the protection or treatment of indigenous peoples during the pandemic has been established, and there is no clear procedure for the access of elderly patients to intensive care units. As of this date, there is also still no disaggregated information on infected or deceased members of indigenous peoples in Chile. The lack of clear protocols and accurate information has been part of general public dissatisfaction with the management of the COVID-19 crisis by the Chilean authorities.

According to the interviewees, authorities have not implemented adequate measures: at present, there is no access protocol for the island or quarantine surveillance for arrivals, and there are no specific terms under which external workers may return to the island. Therefore, the local community has taken its own measures, such as public monitoring of prevention (use of masks and physical distance), voluntary quarantine, avoidance of the local hospital where there were viral

\footnotetext{
${ }^{8}$ Other demands stated in their call were effective contact tracing, isolation and monitoring, establishment of protocols for the development of economic and commercial activities, special protocols in case of contagion by community members, and the prompt arrival of economic support promised by the National Corporation for Indigenous Development.
} 
outbreaks, and broadcasting relevant information by radio and other local media, among others.

As to public and economic activities in Puerto Williams during these months of cordon sanitaire, we note that government agencies are assisting citizens by phone and internet, while trade has functioned with some restrictions. Delivery of provisions and parcel post has continued on a weekly basis from Punta Arenas on the ferry "Yaghán," with some limitations due to the sanitary crisis in the rest of the country. Tourism, based on the natural attractions of the archipelago, has been suspended, and the numerous sailors who visit the island have been confined to the Yacht Club. Likewise, building and telecommunication companies suspended their operations and evacuated their seasonal employees.

The only economic activity that continues operating in a relatively normal manner are the operations of local king crab fishers and the processing plant by the name of Productos Marinos Puerto Williams. These are Puerto Williams' main economic activities followed by tourism and public services, and a strong naval presence. The island supplies global markets, such as China and the USA, with various marine products (mostly king and snow crab). It is thereby typical of the broader Magellan Region, where small-scale fishing and salmon farming make major contributions to employment and income (Campos et al. 2019). Fishing and aquaculture therefore mirror the commodity export model, characteristic of Chilean neoliberalism since the 1980s (Mellado et al. 20192019; Marín et al. 2019). We must note that salmon aquaculture has not been established in the Beagle Channel due to the resistance of non-governmental organizations, local citizens, and the Yagan people (Blanco et al., 2019).

Considering their relevance for the economy, the fact that fisheries have persisted to operate normally is to be expected. This meant that local fishers, some belonging to Yagan families, have continued to go out fishing and that the processing plant has continued functioning ${ }^{9}$. The only restrictions consisted of naval personnel monitoring the harbors and that fishers arriving from other locations were forbidden to come ashore in Puerto Williams. However, landing was allowed in other ports on the island, such as Puerto Toro, where the population was put at risk ${ }^{10}$.

In order to attend to local concerns, weekly meetings came to be organized between authorities, civil society organizations, and indigenous communities as well as trade unions.

\footnotetext{
${ }^{9}$ David Alday, representative of the Puerto Williams Yagan Community reports that approximately 200 workers from the fish processing plant lodge in groups of an average of 15 people, with no clear protection measures and no possible means of social distancing. https://aprensaaustral.cl/cronica/davidalday-vicepresidente-de-la-comunidad-yaghan-de-puerto-williams-tenemosmiedo-que-estas-pestes-nos-afecten-al-igual-que-a-nuestros-antepasados/. Consulted on July 162020

${ }^{10}$ During the month of July, there was the case of an infected fisherman, from Punta Arenas who was working in the Wollastone area. He may have eventually had contact with fishers or local inhabitants at some harbors.
}

This resulted in the establishment of a forum that coordinated support and created a space for attention to local problems.

As to the effects, this pandemic has had on the Yagan community; one of the most significant was the suspension of their periodic meetings (as many as twice a week). The last one took place on March 18th, 2020, to be reactivated in August with very few members in attendance. They have kept in contact by digital means, such as WhatsApp.

Today, most Yagan live in Villa Ukika, on the outskirts of Puerto Williams (see Fig. 2), where community members have resided since the 1960s. They were moved as part of the civilizational process that sought to insert them into local health and education systems through the Chilean state. A few families have homes on other parts of the island, in places like Mejillones Bay and Santa Rosa, and have been able to find shelter there: "We went to Mejillones because life is almost normal there. We could forget what was going on in the world, everywhere. So, we were fine in Mejillones because there we could fish and everything" (Yagan woman 1, June 2020). However, for many Yagan, such relocations do not provide a long-term alternative. Aside from employment in the fisheries, many of them are independent workers with jobs in tourism, building, or arts and crafts. They are among the segment that has been hit the hardest, economically speaking, receiving no steady income at all during this period.

Being gathered in Villa Ukika puts them at risk of contagion. Since the implementation of the cordon sanitaire, there have not been clear and sustained policies for controlling the virus, such as testing and/or effective quarantine of residents or workers who still come and go. This is reflected in the constant appearance of new cases, with no certainty as to where or how they became infected. The Yagan have possibly the same probability of contracting the virus as any inhabitant of Puerto Williams, while sharing places of business, work, public services, and social relations, but their concentration in Villa Ukika makes a large number of their community susceptible to becoming ill at the same time. This would be dramatic since it would put a large part of the ethnic group at risk.

As we will review in the next section, the processes of sedentarization and confinement constitute important issues in the way the colonial relations have developed between Europeans colonists, the Chilean state, and the Yagan of the Cape Horn Archipelago. Sedentarization and confinement around missionary centers and sheep-farming stations resulted in the dissolution of nomadic clan structures and the loss of navigational knowledge and practices. The concentration of Yagan in certain locations also resulted in vulnerability to epidemics and to dramatic instances of demographic decline. The trauma this has caused leads some Yagan to argue that they are alive today because their ancestors fled from these new settlements: "why are we here today?" why do we still exist? Because of the people who would not go to these missions, because of the people who would not gather, but spread 


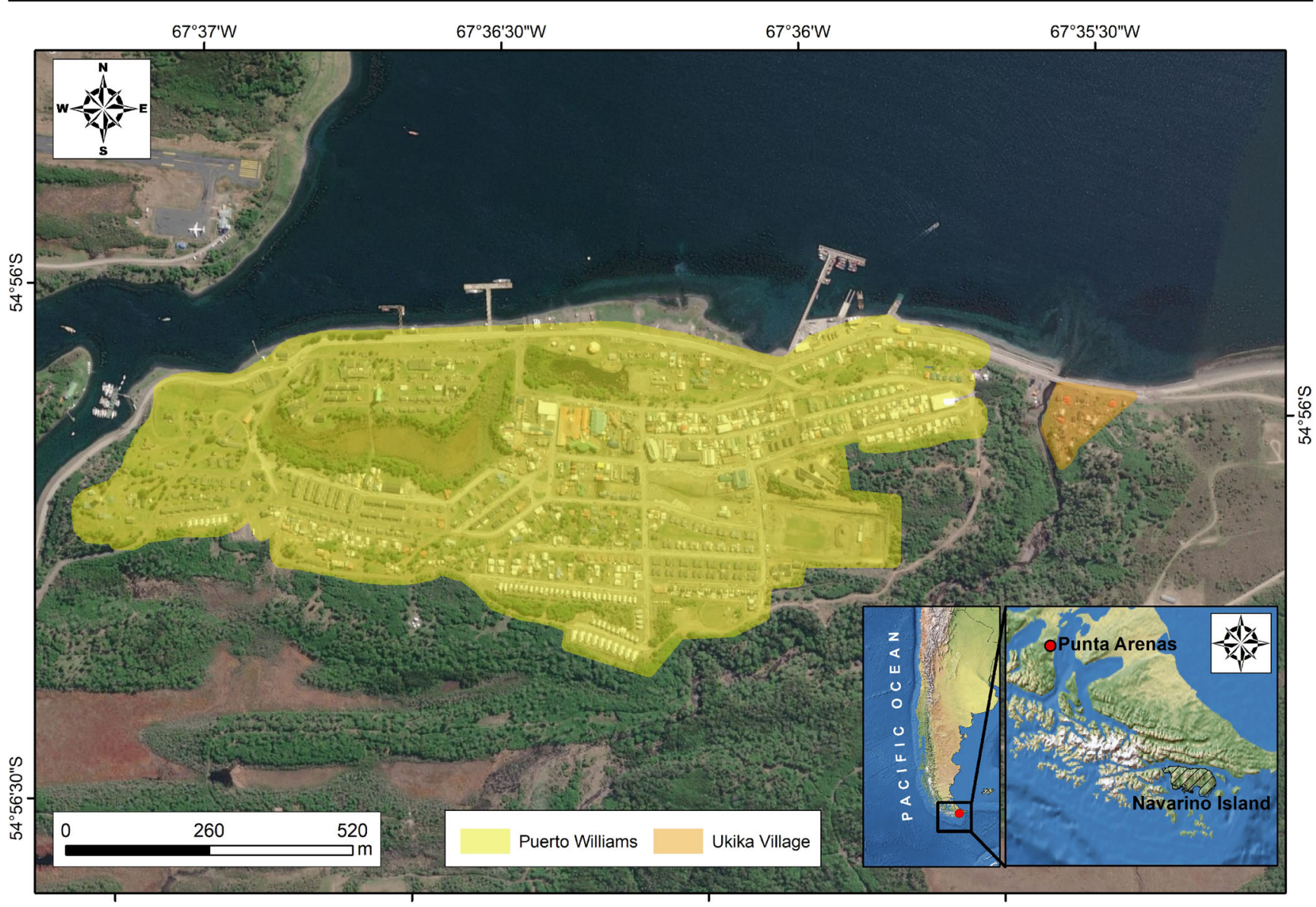

Fig. 2 Satellite image of Puerto Williams and Villa Ukika. Source: authors, based on Google Earth images

out in the territory, that is why we are here. If we had not done that, we would be gone" (Yagan man, June 2020).

\section{Memories}

Evidence of adaptation "towards the predominant exploitation of marine fauna and the development of special technologies to obtain littoral resources" (Orquera and Piana 2009, 104) in the Beagle Channel are first registered having taken place over 6000 years ago. The ancestors of current Yagan based their diet on the hunting of pinnipeds, fish, and birds; the collection of mollusks, eggs, herbs, and fruits; and the utilization of stranded aquatic mammals. Organized in mobile family groups, the southernmost canoe people shared some techniques with the Western Patagonians, the so-called Alacaluf and self-identified as Kawésqar. There is evidence of exchanges with the terrestrial Selknam of Tierra del Fuego and the Aonikenk. The peculiarities of the Yagan, however, are seen in their language, mythologies, taboos, and cultural artifacts as well as their dwelling spaces. Throughout the southern archipelago, the Yagan families were highly independent, although interconnected among groups, with delimited, but not exclusive hunting areas. Fishing and hunting in seasonal cycles, they practiced a nomadism of belonging that secured an abundance of resources, as a society with no scarcity, enjoying much time for non-productive activities. In this, they resemble many other, so-called primitive peoples (Sahlins 1974).

First contacts between Europeans and the southernmost canoe people occurred in the early seventeenth century and were marked by violence; relations were then discontinued for two hundred years until Cook's voyages (Chapman 2012). Between 1830 and 1832, the first registered visit of Fuegians to Europe took place. Taken as hostages by Captain Robert FitzRoy in the British Admiralty's first voyage, they were nicknamed as Jimmy Button, Fuegia Basket, York Minster, and Boat Memory. All four were vaccinated against measles in Montevideo and thereafter in England; Boat Memory contracted measles nonetheless and died soon after their arrival in England (Chapman 2012, 194-212).

The canoe peoples of western Patagonia and the Kawésqar, as well as the Yagan in the southern channels of Tierra del Fuego, did not experience a demographic crisis until the 1880 s (Bridges 2008; Chapman 2012). Although the Yagan had experienced kidnappings, murder, and sexual violence by whalers, seal hunters, and foreign navigators since the earliest European crossings, they did manage to retain their freedom 
Fig. 3 Mrs. Pringle with a group of Yagan children. Anglican Mission at Tekenika Bay, Hoste Island (mid 1890s). Source: http:// patlibros.org. Accessed on August 1, 2020

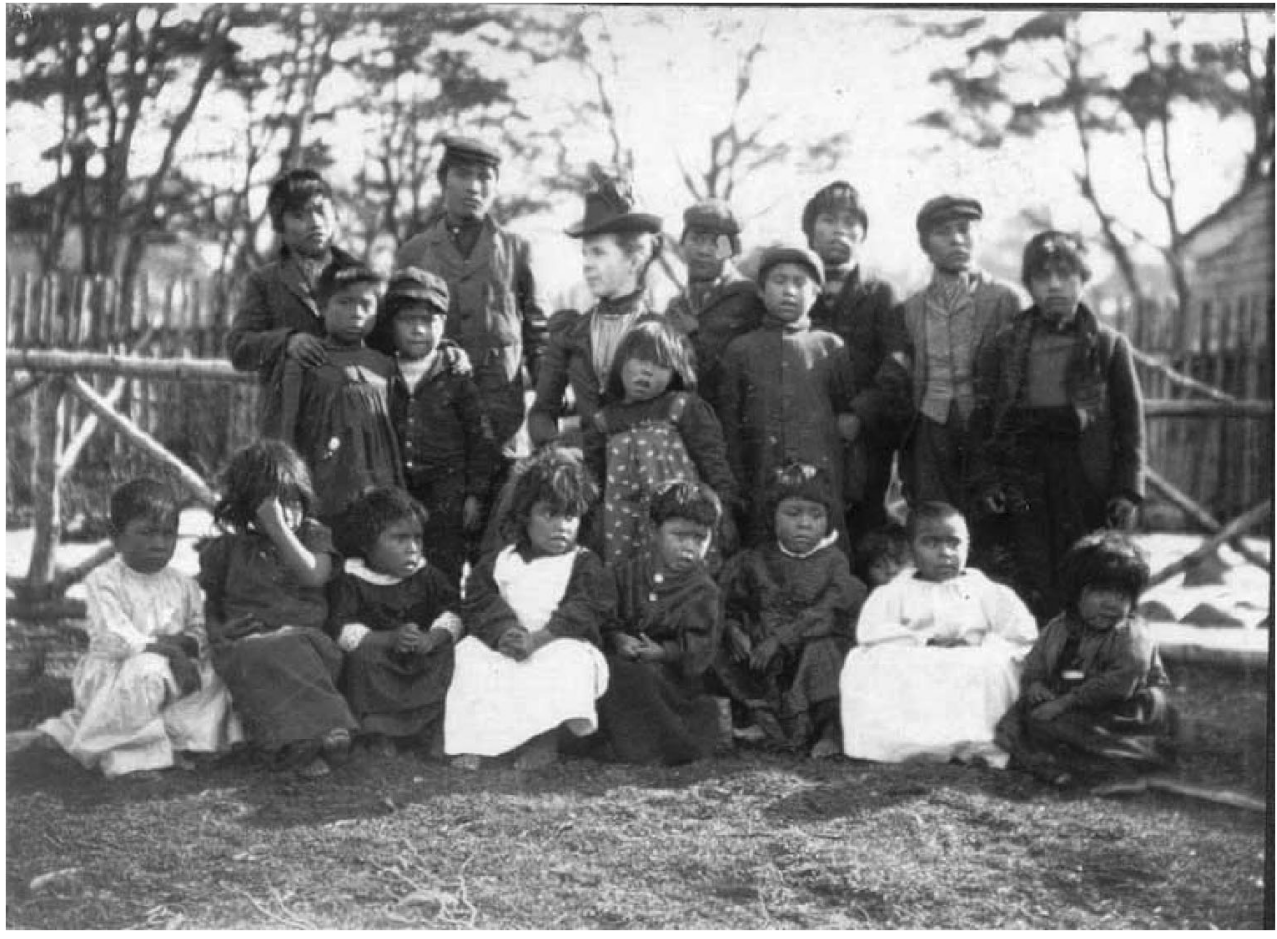

of movement until the time that steamer crossings increased and remote locations began to be occupied by permanent settlers (Hyades and Deniker 1891; Chapman 2012; Harambour and Barrena 2019). A few years after the FitzRoy expeditions, the Brighton-based Patagonian Missionary Expedition made attempts to establish permanent bases in the Yagan territory. With a permanent encampment in the Falkland Islands (Malvinas), the Mission began a civilizing process transporting canoe people whom they referred to as Indians to and from the Fuegian archipelago. In 1869, a permanent mission was established in the bay of Ushuaia, which is now part of Argentina and just across from the area known as Chilean Puerto Williams. Led by Thomas Bridges, a number of British families attempted to convert the Fuegians - a territorial denomination comprised Yagan, Kawésqar, Selknam, and Haush peoples to Christianity, a sedentary lifestyle, and agriculture (Bridges 1998). See Fig. 3 for a photograph of one of these early efforts.

The first outbreak of a pulmonary disease was informed by Bridges to the Missionary Society in June 1882: "with much sorrow I inform the death of many natives, due to a widespread illness affecting the mucous membranes of the throat and lungs." He expressed satisfaction, however, that they had apparently "died in peace, in the love and power of Jesus Christ and knowing God as their Father and Friend" (Bridges 1882 [1998], 121-122). One month later, he notified his superiors that children and women were dying because of a disease that was "taking the natives very quickly" (Bridges 1882 [1998], 127-129). By that time, the visit of the French Mission of La Romanche produced the first foreign view of the activities of the Anglican Missionaries. According to Hyades ${ }^{11}$ and Deniker, "many of the tuberculosis cases we had seen in Ouchouaya, [Ushuaia], in November 1882, died" (Hyades and Deniker 1891, 230) ${ }^{12}$. Before returning to France, the Anglicans allowed them to exhume the bodies of two children and take them to Paris preserved in alcohol. The autopsies concluded they had died from pneumonia and, probably, tuberculosis.

"The onslaught of tuberculosis among the Fuegians living at the English Mission [...] seems to us to be coming from the imported [virus] and other factors" as the "change of habits and regime of the natives, once they were partially civilized," i.e., once they settled. According to Hyades and Deniker, Thomas Bridges thought the deaths were the result of "the harsh climate, as the mortality is much higher between the natives living in a savage stage than those who had settled." For Hyades and Deniker though, this opinion was "in complete disagreement with our observations. The harsh climate is admirably endured, from a physiologic point of view, by the savage Fuegians with whom we lived, and we could not find any dead among them because of the phthisis" (Hyades and Deniker 1891, 230-233).

The correlation between settlement and disease is historically controversial. According to Martin Gusinde, who visited the Yagan at different times in the 1920s, the deaths were

\footnotetext{
${ }^{11}$ Paul Hyades was the first physician and ethnologist to study and diagnose the course of infectious diseases in Cape Horn.

${ }^{12}$ Our translation from original: "Beaucoup des sujets tuberculeux que nous avons vus a Ouochouaya, en novembre 1882, sont morts" (Hyades and Deniker 1891, 230).
} 
mainly the result of the introduction of tuberculosis and measles that took place after European and European-American colonization. The role played by smallpox, whooping cough, typhus, flu, and syphilis was minor, according to the Catholic priest. "Sad gifts given by Europeanism to the Yámanas! The families remaining in the forests did not have contact with the Europeans and kept themselves safe until they shared the sad fate of their tribe's companions." Thus, "the primitive population of about 2500 members of the tribe had descended, by late 1945, to less than 50." Citing news received from Patagonia, he claimed, "there will be no Yámana soon" (Gusinde 1951:121) ${ }^{13}$. Gusinde considered European clothes to be the sources of contagion: "Those who sent clothes for the so poorly dressed savages did not know that the Indians were magnificently accustomed to their extraordinary climate and that nude they had the advantage of receiving the heat from their bonfires directly and abundantly" (Gusinde 1951:122) ${ }^{14}$. According to Penelope Dransart, who wrote about the history of clothing in the Tierra del Fuego, "at the time Gusinde did his fieldwork, people were virtually all wearing Western-style garments. Imported garments were proving to be remarkably unsuitable for their needs. They provided a home for fleas, which were introduced by Europeans along with the clothing" (Dransart 2014, 188).

Increased commercial exploitation of pinniped populations (especially fur seals) by Europeans and US navigators also produced, around the same time, a crisis in the Yagan's "main source of food," forcing them "to survive with less nourishing and scarcer resources" while "infectious diseases for which they had no immunity ravaged populations" (Orquera and Piana 2009, 75). In less than 20 years, the economic and demographic collapse induced the dispersed family groups to settle close to the missions and new sheep-farming stations (Piana and Orquera 2009; Orquera and Piana 2009). Summarizing, "disease, extermination, and the activities of gold seekers and sheep raisers [...] brought about a swift decline" (Valory 1967, 186), in the condition of the Yagan people, forcing the survivors to adjust to their new surroundings.

\footnotetext{
${ }^{13}$ Our translation from original: "Tristes presentes con los que el europeísmo obsequió a los Yámanas! Las familias que por permanecer en el bosque no habían tenido contacto con los europeos se mantuvieron sanas durante algún tiempo hasta que al fin siguieron la misma triste suerte que sus compañeros de tribu." Así, "la primitiva población de cerca de 2.500 miembros de la tribu había descendido a fines de 1945 a poco menos de cincuenta. Así se expresaban las últimas noticias que pude recibir con referencia a este punto. Desde esa fecha ha seguido disminuyendo dicha cifra. Dentro de poco no habrá ningún Yámana” (Gusinde 1951, 121).

${ }^{14}$ Our translation from original: "Los europeos que a petición de los misioneros enviaron sus vestidos a los fueguinos lo habían hecho con la mejor voluntad de remediar el estado de necesidad de los salvajes tan pobremente abrigados. Mas no había pensado ni sabido ninguno de los caritativos bienhechores que los indios estaban acostumbrados magníficamente a su extraordinario clima y que desnudos tenían la ventaja de recibir directa y abundantemente el calor de la hoguera" (Gusinde 1951, 122).
}

Most colonial observers concluded that transculturation under harsh conditions was leading the Indian races to the brink of extinction. The paradigm of extinction has been repeated to this day, further reinforcing the cultural, territorial, and economic invisibility of the southern Patagonian peoples currently inhabiting the archipelago (Lipschutz et al. 1946, 302; Harambour 2017).

Such experiences of life and death are not only recorded in the annals of history but are also etched in the memories of Yagan descendants who tell stories about ancestors who found themselves threatened by the plagues. A particularly remarkable story is that of Carrupakó le kipa also known as "Grandmother Julia" who was born in the Wollastone Islands. According to both oral history and historiography, she sailed alone in her canoe "fleeing from the places where people were crowded" (Yagan woman 2, great-granddaughter of Carrupakó le kipa, 2020). Thus, around 1910, she escaped from the Douglas River Mission and sailed for 2 months, passing through the Posonby Sound, along Nassau Bay, circling the False Cape Horn, crossing the New Year Sound, the Christmas Sound, the west coast of the Hoste Island to return to the Beagle Channel, and the destination of Sambutu, or Mejillones Bay. "Completely alone, rowing with a small oar. When it was calm, she moved fast. She kept a fire on top of pieces of mud or peat. She brought a dog that hunted birds. She also ate eggs and shellfish, and three mussels a day and a bit of water, that was enough" (Cristina Calderón, cited by Chapman 2012, 708).

Yagan people nowadays describe this experience as iconic of their endurance. According to oral accounts, Carrupakó le kipa ran away from the systems of life enforced in the missions: she fled from the imposition of Christianity, from diseases, from jobs destined for women, from European feeding styles, and sedentary ways of living. In times when independent navigation and practices such as hunting, fishing, and gathering were still fully in force, the storytelling about Carrupakó le kipa became an expression of resistance and reexistence of the Yagan people, as well as an effective method to escape the diseases brought by Europeans.

\section{Futurities}

We understand ethnic identities as shared experiences that are constantly redefined based on the relations with other groups and entities. In consonance with this line of thought, the Yagan people are alive, active, and in the midst of what some of its members call "revitalization." But this is not the way it was experienced before. The Yagan of the Cape Horn Archipelago were compelled to change many of their traditional nomadic practices, such as those characterized by the navigation skills portrayed in Carrupakó le kipa's escape. Their drastic demographic decline, forced settlement, and 
changes in livelihoods and language led many authors to create a narrative of extinction or to refer to the elders as "the last ones" 15 (Stambuk, 1986; Guerra 1990). "It is probably unintentional but that term (the last) is used so often as an expression, that deep down it is still a form of genocide, through language use, but still a genocide" (Yagan women 3, July 2020).

Although the SARS-CoV-2 virus and the conditions in which the current pandemic is developing are dissimilar to epidemics that affected them in the past, the fact that the Yagan frequently refer to the past - in press releases, interviews, and online dialogues, among others - constitutes a political action that, in conjunction with a historical review, is evidence of the vibrant existence of a people so often considered extinct or rendered invisible.

In addition to their participation in decision-making processes on the island, some members of the community told us that, for some years now, the Yagan people have focused on cultural revitalization, seeking to recover activities, which due to a sequence of events and colonial relations have been discontinued. "One did not think that the language would be in danger of extinction because all adults spoke it. The children did not speak it because we were not taught by our parents to avoid discrimination at school. Navigation was also restricted. We were forced to use fishing boats of a certain size and you have to have a permit. You also have to wear a life jacket. And so, little by little, we became restricted" (Yagan women 2, July 2020). "Then: Why not reclaim these spaces? Why not navigate and visit our (ancestral) places? Why not return to these places? People used to live and sailed in the archipelago. Why did we stop doing it?" (Yagan women 3, July 2020).

Shared history is important to contemporary Yagan in two ways: on the one hand, their past culture is the source of their ethnic identity; on the other hand, it is a cautionary tale about threats stemming from colonial relations. The past also bestows new vigor and reaffirms their vitality as an ethnic group propelling community imaginations towards the future. Faced with the pandemic, the indigenous demands are about protecting members of the community since they are the living heritage of their people; they are truly bodies of memory and history since, within the framework of their revitalization processes, their lives are their cultural heritage: "There has to be some way to protect our heritage, which is us as a community" (Yagan woman 3, July 2020). In addition to saving individual lives, by reacting to the pandemic, they are protecting their culture as a collective. Therefore, the response to the virus and the management of risk is a political/ethnic process, even when it is not carried out through the enactment of their

\footnotetext{
15 This is also required by the community in point 1 of the protocol of good practices of the Yagan community, requesting that the adjective "last" not be used to refer to people or elements of their culture.
}

traditional practices, but precisely from the work of recovery and protection of this legacy: "First it was the territory, now it is self-care. It is taking care of a community that has fought for the rescue of its culture because here the culture was cut almost at the root (...) defending a territory, defending a culture is much more than asking for a package of social aid" (Yagan woman 3, July 2020).

COVID-19 is seen as a threat but also as an opportunity to project themselves from a different vantage point. Past experiences of resistance have endowed them with experience and political meaning: "And then we had the missionaries. They confined the community. Then the army arrived, then the military coup. It continued as a naval base, and little by little we now have had the strength to be able to speak up and to say things, [and] to also better understand each happening" (Yagan woman 3, July 2020). All this resulted in an organized community, composed of different clans, with a clear and determined voice that has led to some victories ${ }^{16}$. Now, faced with COVID-19, the Yagan are able to make compelling arguments regarding the safeguarding of their culture from a more emancipated position. This is evident, for example, in how, through their first public statement, they urged the government to take action, which leads to a complete lockdown of the island on March 23rd. Through their participation in multisector task groups created because of the pandemic in Puerto Williams, and within their own organization, they have implemented various measures of territorial control related to the care of the elderly and protocols for medical care in Villa Ukika. Yagan people have also led different solidary activities in support of other citizens of Puerto Williams who have been affected during the pandemic.

However, this process of effervescence and action must also overcome important obstacles. How to continue the work of revitalizing your culture and protect yourself from the virus at the same time? Taking into consideration the global call for social isolation as the main measure to avoid contagions, the Yagan community is prevented from continuing to record the stories of their oldest members, nor can they periodically meet in person as they used to, which implies not being able to debate or agree on the issues requiring broad participation. Social isolation has made the task of collectively creating or envisioning a future a complex matter. It prevents, above all, the participation of the elders who are crucial within the revitalization processes that the community is proposing. The main way for their work to go forward depends on the internet,

\footnotetext{
${ }^{16}$ The Yagan community has been very active in recent years, and their struggles have brought what they term victories. In 2017, they mobilized to achieve important housing improvements in Villa Ukika. Later on, they focused on claiming the recovery of their customary rights such as in navigation and traditional ceremonies. In 2018, they achieved the suspension and withdrawal of a road work that involved the construction of a wall in front of Villa Ukika that separated them from the sea, and in 2019, together with other organizations and political groups, they managed to halt the expansion of salmon industry to the Beagle Channel.
} 
which becomes very problematic given that a large part of its members is not familiar with web platforms, many of them have no internet connection, and those who can access internet frequently suffer from connectivity problems. The challenge of how to continue organizing and carrying on with this revitalization process, as well as facing other political disputes in a context of isolation, has become imperative.

The imaginaries that portray the future of the Yagan people are intimately linked to their processes of revitalization from which, connecting with a common past, they can define themselves in relation to others in this globalized world. It is in this process of being cognizant of and nurturing their ethnicity that they project their future and gain momentum. Some initiatives along this line are already underway: the recovery of their language through everyday practicing and linguistic research from some of their members; the reconstruction of their history through photographic archives, documents, and oral stories; the reconnection with islands and significant places within the archipelago; the development of Yagan crafts; and the struggle to recover navigation as an ancestral practice, among others.

As stated above, however, all these activities are carried out in an uncertain terrain due to the pandemic: "We are going to have to do something with the issue of our revitalization, perhaps individually, at home or by phone. I don't know, but we will have to continue working on the subject" (Yagan woman 2, July 2020). Added to the current uncertainty is that of not knowing how the virus and the disease will develop in the region and the world- "There is no knowledge about this virus. There is no vaccine. There is nothing" (Yagan woman 3, July 2020). This uncertainty also halts and hinders the imagination regarding how to continue living and working collectively in a pandemic, or how to resume after it has gone: "We don't know what is really going to happen and obviously what we are doing today is just taking care of ourselves" (Yagan woman 3, July 2020).

Although current times may be unpredictable, there is some certitude. Just as their own lives embody a living heritage that must be protected during this pandemic, the maritory constitutes the fluid space (Ingold, 2009) of their culture. In this sense, the Yagan clans have fought and will continue to defend their territory of life against, for example, the salmon farming companies that threaten it: "We know the damage that it will cause in a territory like ours. If we do nothing, our ancestors will not forgive us. So you have to be careful. They are territories of life, and that has to be respected" (Yagan woman 3, July 2020). In this way, the criticism and struggle of the Yagan Community against extractive and polluting activities are aligned with its political will to sustain itself as an ethnic group.

In relation to other aspects of life in Puerto Williams, there is much uncertainty about the future of private investment projects (such as the Austral Fiber Optic) as well as public works like docks, airports, and tourist infrastructure. All of these projects aim precisely at connecting the island with global flows of people, information, and markets, either in the area of communications and transportation or in the hosting of vacationers. If the lockdown prevails, these activities will remain jeopardized in one way or another.

From the perspective of the inhabitants of Puerto Williams, there is concern that no plans are in place for the local community to take advantage of initiatives and resources once activities restart. They would like environmentally and socially sustainable knowledge and the practices and trades of the Yagan community and other inhabitants of the island to be put at the center of its development strategy. Instead, it seems the authorities prioritize national or foreign investment, hand in hand with a growing estate, and tourism market that smallerscale local initiatives cannot compete with. In the face of a historic constitutional plebiscite held in Chile in October 2020, many of the interviewees have appealed for a constitutional change that will allow the current neoliberal development model to be reoriented. They would also like for the role and rights of native peoples to be rethought.

In this manner, a multiplicity of futures are unfolding for the Yagan Community, and its projections are diverse: from proposals to continue to build tourism, to strengthening as a group in terms of identity formation and livelihoods; others are searching to counteract the effects of neoliberalization on local economic activities, while another group holds radical views that seek to completely detach themselves from the state and globalized capitalism, building from a place and a future not yet imagined.

\section{Multiplicities}

The Mycobacterium tuberculosis and the measles virus have marked the history of the Yagan people just as SARS-CoV-2 is making its distinctive mark now. The becoming of some of these microorganisms into infectious agents for human beings, assembled with political colonizing forces and sociomaterial changes in the archipelago, was the main cause of the drastic population drop of this ethnic group in the past. Viruses and bacteria were also the main agents that provoked their flight from the confinement of missions and sheepfarming stations allowing the descendants of certain clans to survive, albeit being distributed throughout the archipelago.

The sociomaterial organization of these assemblages is permanently transformed; therefore, the actual presence of SARS-CoV-2 interacts with organizational processes of ethnic relations between the Yagan community and the rest of the island dwellers that are very different from those of the past. In the past, the transmission of the virus and the management of the illness were completely aligned with colonial relations. As we have seen, some Yagan were vaccinated or exposed to 
pathogens against their will (those who were forcefully taken to Europe), other bodies were interfered with even after death, and the majority was forcefully confined, accelerating the spread of sickness and, consequently, death. Meanwhile, processes of cultural change were taking place, accelerated by the imposition of European practices, among the most notorious: changes in diet and production, sedentarization, and confinement in missions or sheep-farming stations, changes in clothing, language, and navigation. These material transformations, products of asymmetrical ethnic relations, as stated by Hyades and Deniker, did much to facilitate the spread of these microorganisms (Chapman 2012).

Today the scenario is different, even though asymmetrical power relations persist in different forms. In the current pandemic, the Yagan of Puerto Williams make up part of a larger, diverse population in which everyone is a possible transmitter and victim of that contagion. The Yagan community's demands for protection implicate all island dwellers, in the same way political decisions and social aid concern all inhabitants equally. It was the Yagan community itself that decided against closing Villa Ukika as a means of self-care since they assumed that their members are permanently in contact with people from Puerto Williams and cohabit other spaces.

Even though the risk of contracting the virus is the same for Yagan and non-Yagan, actualized expressions of past colonial relations have a singular meaning for the Yagan, placing tension on their efforts toward ethnic revitalization, as we have noted above. COVID-19 incarnates memories of the effects of a colonial past but also brings present inequality to the forefront. As stated by a Yagan leader: "It will be complicated to start over because the actions the country has taken are not the best, and that is reflected in the number of cases [of infection], which makes us see that we have a horrible health system. That is what is at the bottom of the social uprising of October $2019^{17}$. And we also see it in other things, like education (...) So, there is a chain of things that we have to take into consideration, that are evidence of how the country really is" (Yagan woman 3, July 2020).

\section{Conclusion}

The virus can be conceived as part of an assemblage of bodies, materials, and histories whose effects are also multiplied by the contingencies that arise in different distant places, now rapidly interconnected. Social life is transformed by the suffering of those who contract the illness, the reorganization of

\footnotetext{
${ }^{17}$ Acoording to Garcés $(2019,483)$, "in the week spanning 14 to 18 October 2019, high school students called for massive fare-evasion on the Santiago Metro, meant to protest against the recent fare-hike on this important means of transportation. [...] The conflict slowly escalated, enjoying the tacit support of a large portion of the population." The massive protests lasted several months triggering a political agreement to plebiscite a constitutional change.
}

daily life due to social distancing and self-care, the rearranging of public space because of biosecurity measures of vigilance and control, the changes in livelihoods produced by prolonged lockdown, and the deceleration of the economy of growth.

The aforementioned implies the recognition of the presence or emergence of non-human entities, on the one hand, drastically limiting our humanity, and on the other, granting new lines of flight through the reassembling of new sociomaterial relations. Among those we highlight are, for example: (i) the use of technology and digital means of communication that allow the Yagan people, dealing with the pandemic, to make specific demands visible on different levels, and to coordinate actions with other original peoples; (ii) the confinement restrictions - which are added to those of navigation - allow for conversations projecting the recovery of cultural practices; and (iii) the continuity, by adapted-to-the-pandemic means, of other practices related to Yagan livelihoods.

When it seems that everything is at a standstill in times of quarantine and social distancing, there are actually matters that are multiplied and others that become accelerated, triggering new experiences. We discovered this, in the course of our research process, when the uncertainties unfolded by the virus made our study take on a complex sociomaterial dimension with the risk of becoming agents of infection. It resulted in methodological challenges and in a series of new, collaborative working relationships. Taking a sociomaterial approach allowed us to deal analytically with the interdependence between human communities and non-human entities along the coasts of the Cape Horn archipelago. Within this framework, we reflected on the relation between the current pandemic and past epidemics, as well as on the elements that connect species and ethnic groups in times of disaster.

Within this mosaic of entangled, heterogeneous assemblages (infectious agents-human groups-ecologies), the future projections of these coastal communities are intensified in the face of the uncertainties installed by SARS-CoV-2. Anna Tsing $(2015,23)$ states: “[a]ssemblages don't just gather lifeways; they make them." In this case, the pandemic is a multispecies assemblage with the power to kill some of the entities that constitute it; however, it also allows cooperation, solidarity, and life sustaining actions. Make no mistake, the virus has become an unwelcome entity; yet, its presence on the island has opened a new field for political action for the Yagan people as well as for other indigenous people.

Territories of life and revitalization are specific ways in which Yagan leaders express themselves on the political possibilities that emerge, and which resonate with what certain authors call the politics of life (Charão-Marques et al. 2019). These concepts allow us to focus on those peoples or groups that aim to multiply possibilities for the coexistence of diverse entities, so that space arises for alterity. Such is the case of different practices and concepts related to the ocean, navigation, work, and life that coexist in Puerto Williams and in 
certain cases that are expressed in open rejection of activities considered destructive, such as salmon farming. In this case, the political ontology articulated by Yagan actors is not part of a closed worldview from the past. Instead, it acts to remove certain features of the present, that are felt to affect the Yagan and other inhabitants of the region negatively. The intensified ethnic revitalization in times of the pandemic allows for a vision of an open future, in which there may be multiple ways of assembling reality: "prefiguring livable futures, and quickly refiguring possibilities and changing contingencies, thinkers in biocultural worlds generating surprising becomings" (Kirskey 2020: 50).

The future of Puerto Williams is an open conversation for the Yagan; nurtured in the present of this common past, which, although tragic, is also fertile and allows for the transformation of their ancestors' painful experience into strength, and imagining a less unequal future, or at least one that is more open to the coexistence of alterity. If there is any lesson to be had in these hard times, it is that there is no single, linear way of understanding the effects of the virus; as it brings restrictions, threats, and death, it is also ushering in new forms of political action, new ways of communicating, and new stories for the future.

Acknowledgements We would like to dedicate this work to the families of the Yagan Community, who, while this article was being reviewed, lost one of their members to COVID-19. He was one of their oldest representatives, known, and loved for practicing and teaching the traditional arts of Yagan navigation. We are also grateful to two anonymous referees and the guest editor, Prof. Maarten Bavinck, for their very valuable comments, which led to this revised version.

Funding This work has been funded by grants FONDAP 15150003 and FONDECYT 1201373 both provided by the Chilean National Agency of Research and Development.

\section{Declaration}

Conflict of interest The authors declare that they have no conflict of interest.

\section{References}

Álvarez, Ricardo, Francisco Ther, Juan Carlos Skewes, Carlos Hidalgo, Diego Carabias, and Christian García. 2019. Reflexiones sobre el concepto de maritorio y su relevancia para los estudios de Chiloé contemporáneo. Revista Austral de Ciencias Sociales 36: 115-126. https://doi.org/10.4206/rev.austral.cienc.soc.2019.n36-06.

Bavinck, Maarten, and Jojada Verrips. 2020. Manifesto for the marine social sciences. Maritime Studies 19: 121-123. https://doi.org/10. 1007/s40152-020-00179-x.

Blaser, Mario. 2013. Notes towards a political ontology of 'environmental' conflicts. In: Lesley Green. Contested Ecologies: Dialogues in the South on Nature and Knowledge, (pp. 13-27). Cape Town: HSRC Press.
Blanco, Gustavo, Alberto Harambour, José Barrena, and María Amalia Mellado. 2019. Las disputas sobre el maritorio austral y la revitalización de las identidades canoeras. In: Nahuelhual, L., Gómez, I., Campos, G., Saavedra, G. (eds.) 2019. La región de Magallanes y Antártica Chilena frente al cambio global. Reporte regional Centro de Investigación: Dinámica de Ecosistemas Marinos de Altas Latitudes de la Universidad Austral de Chile. pp: 44-53. https://www.centroideal.cl/wp-content/uploads/2019/12/ Reporte-IDEAL-CHILE-boceto-2911-web.pdf.

Bridges, Thomas. 1998. Los indios del último confin. Sus escritos para la South American Missionary Society. Ushuaia: Zagier \& Urruty.

Bridges, Lucas. 2008. El último confin de la Tierra. Buenos Aires: Sudamericana.

Burawoy, Michael. 1998. The extended case method. Sociological theory 16 (1): 4-33. https://doi.org/10.1111/0735-2751.00040.

Campos, Gonzalo, María Amalia Mellado, Luis Miguel Pardo, Laura Nahuelhual, and Fabio Bozzeda, F. 2019. La pesca artesanal: evolución y desafíos para su sustentabilidad. In: Nahuelhual, L., Gómez, I., Campos, G., Saavedra, G. (eds.) 2019. La región de Magallanes y Antártica Chilena frente al cambio global. Reporte regional Centro de Investigación: Dinámica de Ecosistemas Marinos de Altas Latitudes de la Universidad Austral de Chile. Pp: 22-35. https://www.centroideal.cl/wp-content/uploads/2019/12/ Reporte-IDEAL-CHILE-boceto-2911-web.pdf.

Chandler, David. 2018. Ontopolitics in the Anthropocene: an introduction to mapping, sensing and hacking. London: Routledge.

Chapman, Anne. 2012. Yaganes del Cabo de Hornos. Encuentros con los europeos antes y después de Darwin. Santiago: Pehuén.

Charão-Marques, Flavia, Alberto Arce, and Lorena Fleury. 2019. Desafios analíticos contemporâneos: pós-desenvolvimento e modernidades. Desenvolvimento Rural Interdisciplinar 2 (1): 9-36.

Cupertino, Graziela Almeida, Marli do Carmo Cupertino, Andréia Patrícia Gomes, Luciene Muniz Braga, and Rodrigo SiqueiraBatista. 2020. COVID-19 and Brazilian Indigenous Populations. The American Journal of Tropical Medicine and Hygiene. 103: 609-612. https://doi.org/10.4269/ajtmh.20-0563.

De la Cadena, Marisol and Mario Blaser (Eds). 2018. A world of many worlds. Durham: Duke University Press.

De la Cadena, Marisol. 2015. Earth beings: ecologies of practice across Andean worlds. Durham: Duke University Press.

Deleuze, Gilles, and Felix Guattari. 1988. A thousand plateaus: capitalism and schizophrenia. London: Athlone Press.

Dransart, Penelope (Ed). 2014. Dressed in furs: clothing and Yaghan multispecies engagement in Tierra del Fuego. In: Dransart, Penelope. Living beings: perspectives on interspecies engagements. Bloombsbury Academics.

Escobar, Arturo. 2015. Territorios de diferencia: la ontología política de los "derechos al territorio". Cuadernos de antropología social 41: 25-38. https://doi.org/10.34096/cas.i41.1594.

Ferrante, Lucas, and Philip M. Fearnside. 2020. Protect indigenous peoples from COVID-19. Science 368 (6488): 251-251. https://doi.org/ 10.1126/science.abc0073.

Garcés, Mario. 2019. October 2019: Social Uprising in Neoliberal Chile. Journal of Latin American Cultural Studies 28 (3):483-491

Gonçalves, Jucier, Marcial Moreno Moreira, Woneska Rodrigues Pinheiro, Liromaria Maria de Amorim, Carlos Kennedy Tavares Lima, Claúdio Gleidiston Lima da Silva, and Modesto Leite Rolim Neto. 2020. The mental health of those whose rights have been taken away: an essay on the mental health of indigenous peoples in the face of the 2019 Coronavirus (2019-nCoV) outbreak. Psychiatry Research 289: 113094. https://doi.org/10.1016/j. psychres.2020.113094.

Grusin, Richard. 2015. The nonhuman turn. Minneapolis: University of Minnesota Press. 
Guerra, Ana María. 1990. Yagan. Aspectos culturales de un grupo étnico en vías de extinción. Revista Documentos Lingüísticos y Literarios UACh 16: 11-16.

Gundermann, Hans, and Jorge Iván Vergara. 2009. Comunidad, organización y complejidad social andinas en el norte de Chile. Estudios atacameños 38: 107-126.

Gusinde, Martin. 1951. Hombres primitivos en la Tierra del Fuego (de investigador a compañero de tribu). Sevilla: Escuela de Estudios Hispano-Americanos.

Harambour, Alberto. 2017. Partes del exterminio: la barbarie de la civilización o el genocidio selknam en la Tierra del Fuego. $L a$ Roca 4: 38-58.

Harambour, Alberto, and Jose Barrena. 2019. Barbarie o justicia en la Patagonia occidental: las violencias coloniales en el ocaso del pueblo kawésqar, finales del siglo XIX e inicios del siglo XX. Historia Crítica 71 (january-march): 25-48. https://doi.org/10.7440/ histcrit71.2019.02.

Holbraad, Martin, and Morten Axel Pedersen. 2017. The ontological turn: an anthropological exposition. Cambridge: Cambridge University Press.

Hyades, Paul, and Joseph Deniker. 1891. Mission Scientifique du Cap Horn, 1882-1883. Tome VII. Anthropologie, ethnographie. Paris: Gauthier Villars.

Ingold, Tim. 2009. Point, line and counterpoint: from environment to fluid space. In: Berthoz, Alain and Yves Christen (eds). Neurobiology of "Umwelt": how living beings perceive the world. Springer-Verlag Berlin Heidelberg. pp: 141-155.

Kirksey, Eben. 2020. The emergence of COVID-19: a multispecies story. Anthropology Now 12: 11-16. https://doi.org/10.1080/19428200. 2020.1760631 .

Kohn, Eduardo. 2015. Anthropology of ontologies. Annual Review of Anthropology. 44: 311-327. https://doi.org/10.1146/annurevanthro-102214-014127.

Linde-Ozola, Zane. 2020. COVID-19 and human-virus relationality. Social Anthropology. 28: 304-306. https://doi.org/10.1111/14698676.12855 .

Lipschutz, Alexander, Grete Mostny, and Louis Robin. 1946. The bearing of ethnic and genetic conditions on the blood groups of three Fuegian tribes. American Journal of Physical Anthropology 4: 301322. https://doi.org/10.1002/ajpa.1330040311.

Marín, Sandra, Ximena Vergara, Fabio Bozzeda, Gonzalo Campos and Gustavo Blanco. 2019. La salmonicultura en la región de Magallanes y sus efectos en el espacio marino-costero. In: Nahuelhual, L., Gómez, I., Campos, G., Saavedra, G. (eds.) 2019. La región de Magallanes y Antártica Chilena frente al cambio global. Reporte regional Centro de Investigación: Dinámica de Ecosistemas Marinos de Altas Latitudes de la Universidad Austral de Chile. pp: 37-43. https://www.centroideal.cl/wp-content/uploads/ 2019/12/Reporte-IDEAL-CHILE-boceto-2911-web.pdf.

Mather, Charles, Jahn Petter Johnsen, Signe Sonvisen, Aarthi Sridhar, and Johny Stephen. 2017. Introduction to the themed issuepoststructural approaches to fisheries. Maritime Studies 16 (1): 20. https://doi.org/10.1186/s40152-017-0074-4.

McLeod, Melissa, Jason Gurney, Ricci Harris, Donna Cormack, and Paula King. 2020. COVID-19: we must not forget about indigenous health and equity. Australian and New Zealand journal of public health. 44: 253-256. https://doi.org/10.1111/1753-6405.13015.

Mellado, María Amalia, Gustavo Blanco-Wells, Laura Nahuelhual, Gonzalo Saavedra. 2019. Livelihood trajectories in the Chilean Patagonian region: an ethnographic approach to coastal and marine socioecological change. Regional Environmental Change 19 (1): 205-217. https://doi.org/10.1007/s10113-018-1398-3

Meneses, Sergio, María Graciela Freyermuth, Blanca Pelcastre, Roberto Campos, David Meléndez, and Liliana Flores. 2020. The challenges facing indigenous communities in Latin America as they confront the COVID-19 pandemic. International Journal for Equity in Health 19: 1-3. https://doi.org/10.1186/s12939-020-01178-4.

Orquera, Luis, and Ernesto Piana. 2009. Sea nomads of the Beagle Channel in Southernmost South America: over six thousand years of coastal adaptation and stability. The Journal of Island and Coastal Archaeology 4: 61-81. https://doi.org/10.1080/ 15564890902789882.

Piana, Ernesto, and Luis Orquera. 2009. The southern top of the world: the first peopling of Patagonia and Tierra del Fuego and the cultural endurance of the Fuegian Sea-Nomads. Arctic Anthropology 46: 103-117. https://doi.org/10.1353/arc.0.0023.

Postill, John. 2017. Remote ethnography. Studying culture from afar. In: Hjorth, Larissa, Heather Horst, H, Anne Galloway and Genevieve Bell (Eds.). The Routledge companion to digital ethnography. Taylor \& Francis. p.p: 61-69.

Pauwelussen, Annet. 2020. Commentary 11 to the manifesto for the marine social sciences: culture and religion. Maritime Studies 19, 147149. 10.1007

Power, Tamara, Denise Wilson, Odette Best, Teresa Brockie, Lisa Bourque, Eugenia Millender, and John Lowe. 2020. COVID-19 and indigenous peoples: an imperative for action. Journal of Clinical Nursing. Journal of clinical nursing 29 (15-16): 27372741. https://doi.org/10.1111/jocn.15320.

Sahlins, Marshall. 1974. La economía de la Edad de Piedra. Madrid: Akal.

Searle, Adam, and Jonathon Turnbull. 2020. Resurgent natures? Morethan-human perspectives on COVID-19. Dialogues in Human Geography. https://doi.org/10.1177/2043820620933859.

Stambuk, Patricia. 1986. Rosa Yagán, el último eslabón. Santiago: Chile.

Tsing, Anna. 2015. The mushroom at the end of the world. New Jersey: Princeton University Press.

Valory, Dale. 1967. Folklore of the Fuego-Patagonian peoples: annotated bibliography. Behavior Science Notes 3: 175-202. https://doi.org/ 10.1177/106939716700200301.

Wade, Lizzie. 2020. An unequal blow. Science 368: 700-703. https://doi. org/10.1126/science.368.6492.

White, Alexander. 2020. Historical linkages: epidemic threat, economic risk, and xenophobia. The Lancet 395 (10232): 1250-1251. https:// doi.org/10.1016/S0140-6736(20)30737-6.

Wolfe, Cary. 2010. What is posthumanism? Minneapolis: University of Minnesota Press.

Publisher's note Springer Nature remains neutral with regard to jurisdictional claims in published maps and institutional affiliations. 